\section{Woody Species Diversity of Parkland Agroforestry in Ethiopia}

\section{Melese Worku}

Departments of Forestry, Faculty of Agriculture and Environmental Sciences, Deber Tabor University, Deber Tabor, Ethiopia

*Corresponding author: Melese Worku, Departments of forestry, Faculty of Agriculture and Environmental Sciences, Deber Tabor University, Deber Tabor, Ethiopia, Tel: +251-913 986 518, E-mail: Melese1980@gmail.com

Received date: September 07, 2017; Accepted date: September 22, 2017; Published date: September 27, 2017

Copyright: (c 2017 Worku M. This is an open-access article distributed under the terms of the creative commons attribution license, which permits unrestricted use, distribution, and reproduction in any medium, provided the original author and source are credited.

\begin{abstract}
Parkland agroforestry system has a crucial role in social, economic and environmental value. For instance, woody tree in Parkland improve soil fertility and enhancing crop productivity. Parkland tree have a potential of AM colonization and increase soil moisture to facilitate microbial activity. Park land agroforestry is a system where farm crops are mixed with trees to supply fodder, fuel, leaf litter, medicinal herbs, fruit, timber, etc. Predictably, the farmers have only grown a single crop on one field. Also, there is a belief that crops cannot grow well in the shade of nearby trees, so trees will often be cleared from cropland. In the days when there was plenty of forest near to the village, there was no shortage of fuel, fodder, etc. But now, overcutting of fodder, firewood, timber, etc., and grazing livestock, has destroyed the forests. So farm yields have become lower and lower. More landslides have been an extra problem. By planting parkland land agroforestry, farm needs for fodder, timber, fuel, etc. can be met as well as protecting the environment.
\end{abstract}

Keywords: Parkland agroforestry system; Mycorrhizal tree; Woody species

\section{Introduction}

Parkland savanna may be defined as the regular presence of wellgrown trees scattered on cultivated or recently fallowed fields. The trees are deliberately associated with the agricultural environment because of their specific use. Parklands are generally understood as landscapes in which mature trees occur scattered in cultivated or recently fallowed fields [1], the coexistence of woody plants and grasses in subtropical and tropical savanna ecosystem called parklands [2]. In park land systems, the woody plant component is comprised of $\mathrm{C} 3$ species and the crop of C4 (including grass weeds). On other hand, a major reason for practicing agroforestry land use systems is domestication of soilimproving trees for enhancing soil productivity through a combination of selected trees and food crops on the same farm field [3].

In the ICRAF Agroforestry Systems Inventory, agroforestry parklands are included in the very general category of 'multipurpose trees on farmlands'. Woody species in parkland are often critical components of a farmers' environment being a source of products and environmental services of importance to the farmers' livelihood and welfare. Recently, it has been recognized that the part played by the woody species in these landscapes play an important role in maintaining biological diversity [4].

\section{Objectives}

The overall aim of this review is to understand woody species diversity parkland agroforestry in Ethiopia.

\section{Concept of Parkland Tree}

In the tropics, conservationists have focused their attention on the protection of natural forests and woodlands, and until recently [4] have not given much attention to the widely dispersed on-farm woody species.

These patches are often critical components of a farmers' environment being a source of products and environmental services of importance to the farmers' livelihood and welfare. Recently, it has been recognized that the part played by the woody species in these landscapes play an important role in maintaining biological diversity $[4,5]$.

The agroforestry parkland system in the semi-arid West Africa, which has supported farmers' life for centuries because of the diversity of plant resources it provides, is under serious threat due to the increasing population pressure on the agricultural lands [5].

A major reason for practicing agroforestry land use systems is domestication of soil-improving trees for enhancing soil productivity through a combination of selected trees and food crops on the same farm field [3].

\section{Woody Species Diversity of Parkland Agroforestry}

\section{Tree species diversity in parkland agroforestry}

Diversity is used to compute for species richness and species evenness of the plant community types in the vegetation.

Species richness is the number of species per given area where as species Evenness is the relative abundance of species to all species or an even distribution of individual species. Various studies on woody species diversity of parkland Agroforestry report different diversity from different part of the regions (Table 1). 


\begin{tabular}{|l|l|l|l|l|}
\hline Place of studies & $\begin{array}{l}\text { Shannon } \\
\text { diversity }\end{array}$ & $\begin{array}{l}\text { Species } \\
\text { richness }\end{array}$ & Evenness (J) & Name of Authors \\
\hline Arbegona District, Ighlands of Southern Ethiopia & 2.52 & 108 & 0.58 & Muktar Reshad, 2006 \\
\hline Libo kemkem Zone, Ethiopia & 2.53 & 34 & 0.9 & worku Melese,2017 \\
\hline Semi-Arid West Africa, Burkina Faso & 1.947 & 56 & 0.856 & Nikiema, 2005 \\
\hline
\end{tabular}

Table 1: Diversity of woody species in parkland agroforestry.

The study by Aklilu Agidie et al. on the Agroforestry Practices and Farmers' Perception in Koga Watershed, Upper Blue Nile Basin, Ethiopia revealed that the major trees found on-farm lands and which were deliberately left by the farmers were Croton macrostachys, Acacia abyssinica and Cordia africana [6].

\section{Biological property of soil under parkland}

The primary processes held responsible for the formation of high fertility islands around trees relate to enhanced biological processes associated with the seasonal and long-term return of nutrients accumulated in trees to the soil through litter fall, root decay and exudation, and their mineralization, as well as leaching of nutrients stored in canopies.

In tropical ecosystems, wild fruit-bearing species play multiple roles in ecosystem biodiversity conservation and improvement of rural populations' food situation and income through sales and consumption of fruits. Among these species, we can cite Ziziphus mauritiana, Balanites aegyptica, Tamarindus indica, Adansonia digitata and Ximenia americana. Furthermore, wild fruit trees are used in traditional medicine and also as a source of wood [7].

The study by Mengsteab Hailemariam et al. on Arbuscular mycorrhizal association of indigenous agroforestry tree species and their infective potential with maize in the rift valley, Ethiopia indicated the potential benefits of standing farm trees on maintaining the sources of inoculum for agricultural crops [8]. The difference in AM fungi spore density under and outside the canopy of the two tree species might be due to the fact that mycorrhizal tree roots could increase the number of spores in the soil, which results in higher number of spores under the canopy of both trees. Level of root colonization percentage decreased with increasing distance from trunk of both tree species (Table 1). The average colonization percentage of C. macrostachyus tree roots across all horizontal distances was $9 \%$ higher than A. gummifera roots.

On other hand, this study revealed that significantly higher number of spores and level of root colonization of $Z$. mays grown under the canopy of $A$. gummifera and $C$. macrostachyus trees than outside the canopy [8]. Soils under the canopy of $C$. macrostachyus trees resulted in higher spore abundance and level of root colonization than soils from A. gummifera.

\section{Nitrogen Fixation}

One reason is that few woody species have been reported to nodulate naturally in the Sahel and Sudan zones of West Africa. While nodulation is common for $F$. albida seedlings, $\mathrm{N}$-fixation is rarely reported in adult trees. Therefore, the contribution of increased soil nitrogen under $F$ albida due to N-fixation is limited. One could hypothesize that some degree of $\mathrm{N}$-fixation continues into adult tree age in agroforestry parklands, where nitrogen is extracted by crops and mostly not returned to the soil.

The lack of difference in soil nitrogen beneath Adansonia digitata and the leguminous Acacia tortilis indicated that nitrogen enrichment under these trees was not related to $\mathrm{N}$-fixation [9]. Other leguminous parkland species such as P. biglobosa do not nodulate in the field or in the greenhouse. N-fixation is mostly limited by low availability of phosphorus, which is one of the most common nutrients limiting plant production in semi-arid regions [10].

\section{The extent of parkland agroforestry practices in Ethiopia}

This practice involves the growing of individual trees and shrubs in wide spaces in croplands. Dispersed trees grown in farmlands characterize a large part of the Ethiopian agricultural landscape. Trees would be grown in a scattered form over a crop field, usually between 1-20 trees per hectare to minimize impact on the companion crop. In such mixed intercropping, lopping and pollarding of trees would be practiced. Some good examples of this practice include Cordia africana intercropping with maize in Bako and western Ethiopia; Acacia albida based agroforestry in the Hararghe Highlands and Debrezeit area [1].

\section{Conclusion}

From the reviewed books and journals, I concluded woody tree and shrubs in Parkland agroforestry system have a crucial role in social, economic and environmental value. For instance, Woody tree in Parkland improve soil fertility and enhancing crop productivity. Parkland tree have a potential of AM colonization and increase soil moisture to facilitate microbial activity.

\section{References}

1. Bishaw B, Abdelkadir A (2003) Agroforestry and Community Forestry for Rehabilitation of Degraded Watersheds in the Ethiopian Highlands. Intern Symp Contemporary Devel Iss Ethiopia 78.

2. Bayala J, Balesdent J, Marol C, Zapata F, Teklehaimanot Z, et al. (2007) Relative contribution of tree and crops to soil carbon content in a parkland system in Burkina Faso variations in natural 13C abundance. Nutrient Cycling in Agroecosystems 76: 161 - 169.

3. Kassa H, Gebrehiwet K, Yamoah C (2010) Balanites aegyptiaca, a potential tree for parkland agroforestry systems with sorghum in Northern Ethiopia. J Soil Sci Environ Manage 1: 107-114.

4. Schelas J, Greenberg R (1996) Forest Patches in Tropical Landscapes. J Appl Ecol 34: 544.

5. Nikiema A (2005) Agroforestry parkland species diversity: Uses and Management in Semi-Arid West Africa (Burkina Faso), Wageningen University, Wageningen. 
Citation: Melese W (2017) Woody Species Diversity of Parkland Agroforestry in Ethiopia. Global J Technol Optim 8: 218. doi: $10.4172 / 2229-8711.1000218$

Page 3 of 3

6. Agidie A, Ayele B, Wassie A, Hadgu KM, Aynekulu E, et al. (2013) Agroforestry Practices and Farmers' Perception in Koga Watershed, Upper Blue Nile Basin, Ethiopia. J. Agric for 59: 75-89.

7. Diouf M, Bourou S, Ndiaye F, Diop T, Damme PV (2010) Tamarind (Tamarindus indica L.) parkland mycorrhizal potential within three agroecological zones of Senegal. Fruits 65: 1-13.

8. Hailemariam M, Birhane E, Asfa Z, Zewdie S (2013) Arbuscular mycorrhizal association of indigenous agroforestry tree species and their infective potential with maize in the rift valley, Ethiopia. An Intern Journ incorporating Agrofor Forum 87: 1261-1272.

9. Bationo A, Waswa B, Kihara J, Kimetu J (2007) Advances in Integrated soil fertility management in Sub-saharan Africa:Challenge and Opportunities.

10. Worku M (2017) The Role of Forest Biodiversity Conservation Practices for Tourism Development in a Case of Tara Gedam Monastery, South Gonder Zone, Ethiopia. J Ecosyst Ecography 7: 1-6. 